\title{
Faunistic assemblages of a sublittoral coarse sand habitat of the northwestern Mediterranean
}

\author{
EVA PUBILL ${ }^{1}$, PERE ABELLÓ ${ }^{1}$, MONTSERRAT RAMÓN ${ }^{2,1}$ and MARC BAETA ${ }^{3}$ \\ ${ }^{1}$ Institut de Ciències del Mar (CSIC), Passeig Marítim de la Barceloneta, 37-49, 08003 Barcelona, Spain. \\ E-mail: mramon@icm.csic.es \\ ${ }^{2}$ Instituto Español de Oceanografía, Centre Oceanogràfic de les Balears, Moll de Ponent s/n, \\ 07015 Palma de Mallorca, Spain. \\ ${ }^{3}$ Tecnoambiente S.L., carrer Indústria, 550-552, 08918 Badalona, Spain.
}

SUMMARY: The sublittoral megabenthic assemblages of a northwestern Mediterranean coarse sandy beach exploited for the bivalve Callista chione were studied. The spatial and bathymetric variability of its distinctive faunal assemblages was characterised by quantitative sampling performed with a clam dredge. The taxa studied were Mollusca Bivalvia and Gastropoda, Crustacea Decapoda, Echinodermata and Pisces, which accounted for over $99 \%$ of the total biomass. Three welldifferentiated species assemblages were identified: (1) assemblage MSS (Medium Sand Shallow) in medium sand (D50=0.37 $\mathrm{mm}$ ) and shallow waters (mean depth $=6.5 \mathrm{~m}$ ), (2) assemblage CSS (Coarse Sand Shallow) in coarse sand (D50=0.62 $\mathrm{mm})$ in shallow waters (mean depth $=6.7 \mathrm{~m}$ ), and (3) assemblage CSD (Coarse Sand Deep) in coarse sand (D50=0.64 mm) in deeper waters (mean depth $=16.2 \mathrm{~m}$ ). Assemblage MSS was characterised by the codominance of the bivalves Mactra stultorum and Acanthocardia tuberculata. C. chione was dominant in both density and biomass in assemblages CSS and CSD. The occurrence of the crab Thia scutellata also characterised assemblage CSS, whereas the occurrence of the sea urchin Echinocardium mediterraneum characterised assemblage CSD. A depth breaking point of around $10 \mathrm{~m}$ determined the discontinuity between assemblages CSS and CSD, which was related to the closure depth of the beaches in the study area. Species richness was highest in the coarse sand communities; however, Shannon-Wiener diversity and Pielou equitability indexes were higher in the shallow fine sand community.

Keywords: sublittoral, megabenthos, faunal assemblages, sediment characteristics, biodiversity, NW Mediterranean, coarse sand, Bivalvia, Crustacea.

RESUMEN: Comunidades faunísticas de un hábitat SUblitoral de arena GRuesa EN el MediterRáneo NorocCIDENTAL. - Se han estudiado las comunidades megabentónicas sublitorales de playas de arena gruesa afectadas por la pesquería del bivalvo Callista chione en el Mediterráneo noroccidental (Maresme). Se ha caracterizado la variabilidad espacial y batimétrica de las comunidades faunísticas presentes mediante un muestreo cuantitativo utilizando un rastrillo de bivalvos. Los taxones estudiados fueron Mollusca Bivalvia y Gastropoda, Crustacea Decapoda, Echinodermata y Pisces, los cuales representaron más del $99 \%$ de la biomasa total. Se identificaron tres comunidades bien diferenciadas: (1) comunidad MSS en arenas medias (D50 $=0.37 \mathrm{~mm}$ ) y poco profundas (profundidad media $=6.5 \mathrm{~m}),(2)$ comunidad CSS en arena gruesa (D50=0.62 mm) en aguas someras (6.7 m), y (3) comunidad CSD en arenas gruesas (D50=0.64 $\mathrm{mm}$ ) en aguas más profundas $(16.2 \mathrm{~m})$. La comunidad MSS se caracterizó por la codominancia de los bivalvos Mactra stultorum y Acanthocardia tuberculata. C. chione dominó en densidad y biomasa en las comunidades CSS y CSD. La presencia del braquiuro Thia scutellata también caracterizó la comunidad CSS, mientras que la presencia del erizo Echinocardium mediterraneum caracterizó la comunidad CSD. Se detectó una discontinuidad entre las comunidades CSS y CSD a una profundidad de unos $10 \mathrm{~m}$, la cual está relacionada con la profundidad de cierre de las playas del área de estudio. La riqueza específica fue mayor en las comunidades de arena gruesa, no obstante los índices de diversidad de Shannon-Wiener y de equitabilidad fueron superiores en la comunidad de arenas finas.

Palabras clave: sublitoral, megabentos, comunidades faunísticas, características del sedimento, biodiversidad, Mediterráneo noroccidental, arena gruesa, bivalvos, crustáceos. 


\section{INTRODUCTION}

Sandy beaches are ecosystems under increasing anthropogenic pressures, both from direct human impact (coastal development, tourism, recreation and/ or fishing) and indirect causes such as sea level rise (McLachlan et al., 1996; Sardá et al., 2000; Schlacher et al., 2007). The fauna hosted by sandy beaches is well adapted to the strong dynamic environmental processes that take place in such extreme habitats, such as wide and sudden changes in temperature and salinity, waves associated with storms and tides, etc. (Berghahn, 2000; Defeo and McLachlan, 2005; Schlacher et al., 2007). However, and despite their apparent resilience, beaches can be categorised as sensitive habitats, although they are inhabited by pioneering, physiologically strong species (McLachlan et al., 1995; Schoeman et al., 2000). Given their dynamic environment, beaches and associated infralittoral systems generally have high biological productivity, and therefore constitute important recruitment areas for many fish and mobile invertebrates, many of them of commercial interest (Benfield and Downer, 2001; Selleslagh and Amara, 2008).

The physical dynamics of beach ecosystems, together with the characteristics of the sediment, allow the formation of a gradient of beach morphodynamic states, from steep reflective to flat dissipative beaches (Wright and Short, 1984; Brown and McLachlan, 1990). Accordingly, the species composition and biological community structure of sandy beaches have been found to vary in relation to sediment characteristics, beach morphology and depth, as well as biogeography (Brazeiro, 2001; Lastra et al., 2006; Dolbeth et al., 2007, 2009; Rufino et al., 2008, 2010).

Studying the spatial patterns of species distribution is essential for understanding the scales at which organisms interact with each other and with their environment (Underwood and Chapman, 1996). The ecology of benthic macro-invertebrates in beaches and soft sediment environments has been reviewed by several authors (Constable, 1999; McLachlan and Dorvlo, 2005; Defeo and McLachlan, 2005), by analyzing the spatial distribution and the biotic and abiotic processes involved in shaping the actual characteristics of the observed present distributions. Information on the composition and structure of benthic communities is therefore important for understanding energy pathways, for ecosystem-based fishery management of the exploited species and associated communities, and for the conservation of the environment.

Not many studies have focused on analysing the megabenthos composition, community structure and dynamics of beaches and adjacent infralittoral systems in the western Mediterranean. As most beaches in the area are medium to fine sand dissipative beaches, there are few studies on coarse sand beaches in the area. Some of the studies performed on coarse sand infralittoral bottoms of reflective beaches in the western
Mediterranean have studied the seasonality of macrofaunal dynamics of fine to coarse sand infralittoral areas (Sardá et al., 1999, 2000), the suprabenthos of several types of beaches (Munilla and San Vicente, 2005), or the megabenthic fauna of the north Alboran Sea (Salas Casanova et al., 1985; García-Raso, 1987; García Muñoz et al., 2008).

The main objective of the present study was to characterise the megabenthic community of an exploited infralittoral coarse sand area with reflective beaches in the northwestern Mediterranean (Maresme region, north of Barcelona) in order to obtain ecological information useful for the sustainable management of the bivalve Callista chione fishery. The sampling schedule took into account the identification of the benthic species present in the area, their quantification in terms of density and biomass and their spatial structure according to bathymetry and location along the coast, as well as the associated information on sediment characteristics and community structure.

\section{MATERIALS AND METHODS}

\section{Study area and sampling}

The study area was located northeast of Barcelona, in the northwestern Mediterranean Sea, along a coastal strip of shallow bottoms characterised by coarse granitic sand. It has a straight wave-dominated coastline. The beaches are of a reflective type and sediments originate from the erosion of degraded granite from the nearby mountains carried by short rivers, such as the Tordera, and seasonal intermittent streams (torrents); the most probable significant wave height is $0.5 \mathrm{~m}$, with a wave period of $3 \mathrm{~s}$ (Sorribas et al., 1993). Large NE-E storm events are recorded from October to December, which affect the seafloor down to a water depth of ca. $20 \mathrm{~m}$. Human actions related to dredging operations (beach nourishment and infilling of the harbour entrance) have a local impact on the sedimentary system (Ercilla et al., 2010).

A total of 44 sampling stations were distributed along 16 transects perpendicular to the coast, placed at $4 \mathrm{~km}$ intervals (Fig. 1). Transects were consecutively numbered from north to south (T01-T16). There were 4 stations per transect. Samples were taken at 5, 10, 20 and $30 \mathrm{~m}$, whenever possible (bottom heterogeneity, seagrass and rocky outcrops permitting).

Sampling was performed in November-December 2004 on board the F/V "Nautes", an artisanal fishing boat (10 m length; $100 \mathrm{HP}$ ) involved in the bivalve fishery. The gear used was a clam dredge, locally known as "gàbia de lluenta", with a smaller mesh size than the commercial one to allow juvenile individuals to be caught (mouth width: $70 \mathrm{~cm}$; mouth height: $53 \mathrm{~cm}$; depth $120 \mathrm{~cm}$; steel mesh size: $12 \times 12 \mathrm{~mm}$ ). The mean towed area per sample was $318 \mathrm{~m}^{2}$, and the distance between the start and finish of the tow was estimated by GPS readings. 


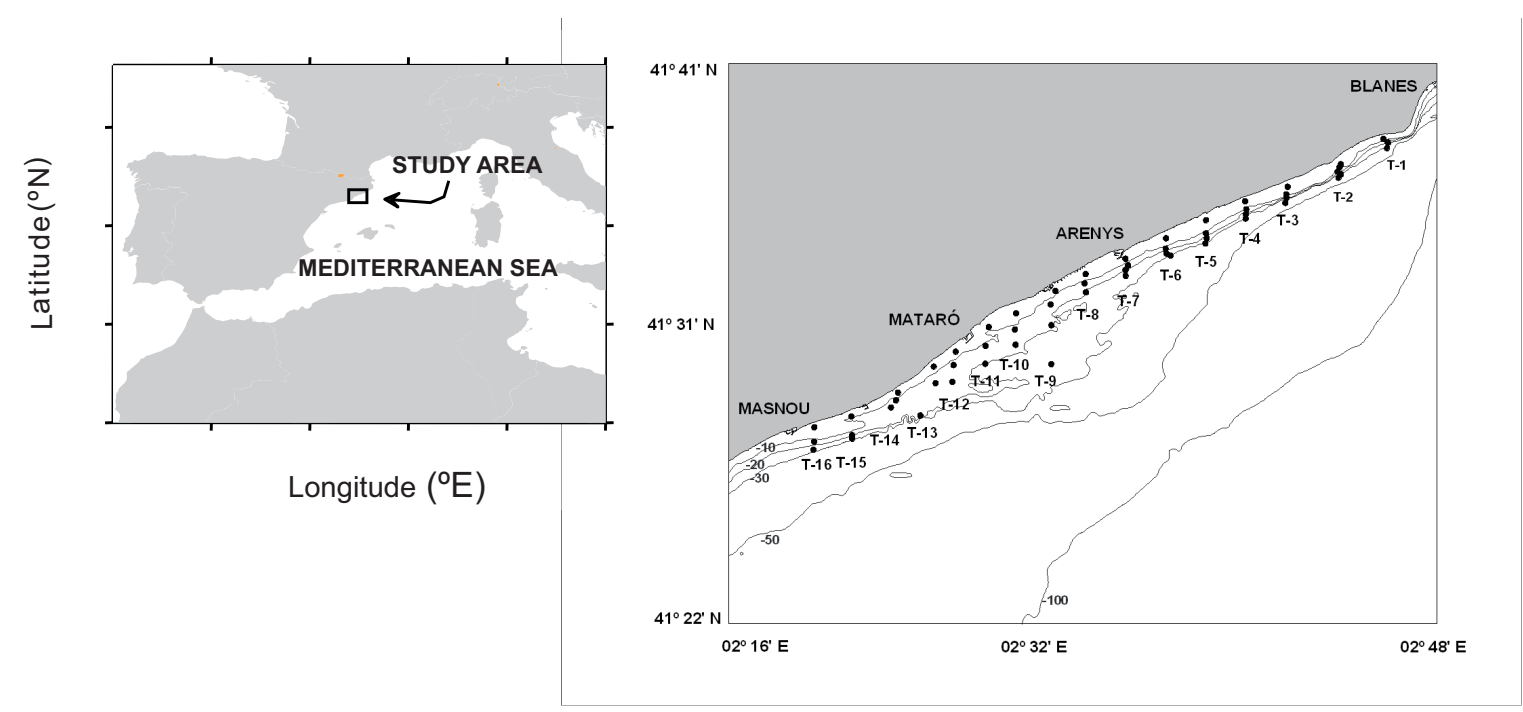

FIG. 1. - Location of the study area in the northwestern Mediterranean Sea, in the vicinity of Barcelona.

In the laboratory, the catch was sorted to species level, and total abundance (number of individuals per sample) and biomass (in g) per species was obtained. Densities were later calculated taking into account the swept area, and presented as number of individuals or $\mathrm{g}$ per $200 \mathrm{~m}^{2}$. The taxa studied were Mollusca Bivalvia, Mollusca Gastropoda, Crustacea Decapoda, Echinodermata and Pisces, which accounted for over $99 \%$ of the total biomass.

Sediment samples were collected at each station with a $7 \mathrm{~cm}$ diameter x $30 \mathrm{~cm}$ length cylindrical container attached to the sampling gear and towed on the sediment surface. To obtain the granulometric composition, the sediment samples were treated according to the standard protocol: the sediment was oven-dried at $70^{\circ} \mathrm{C}$ for $72 \mathrm{~h}$, treated with $0.2 \mathrm{~N} \mathrm{NaOH}$ solution and stirred to release silt and clay particles and then sieved through decreasing mesh-sized sieves: $2 \mathrm{~mm}$ (gravel), 2.0-1.0 $\mathrm{mm}$ (very coarse sand), 1.0-0.5 mm (coarse sand), 0.5-0.25 mm (medium sand), 0.25-0.125 mm (fine sand), 0.125-0.063 mm (very fine sand); smaller particles were classified as silt-clay. The median size of the particles (D50) was also calculated. For each faunistic assemblage obtained through cluster analysis (see below), a master sediment profile sample (Guillén and Hoekstra, 1997) was obtained by calculating the median value of the relative abundance of each grain size fraction from all samples taken within each assemblage.

\section{Data analyses}

Multivariate analyses were based on the matrix of species density per sample after logarithmic transformation $(\log (\mathrm{x}+1))$ using PRIMER v5 (Clarke and Warwick, 1994). Species occurring in less than $8 \%$ of the samples, and samples with less than three species were excluded from these analyses. A total of 36 sam- ples were accordingly analysed. Similarities among samples based on their species composition were calculated using the quantitative Bray-Curtis coefficient. Cluster and non-metric multidimensional scaling (MDS) were used to describe the overall relationship between species and samples and thus identify species assemblages. The Unweighted Pair Group Method with Arithmetic Mean (UPGMA) was used as the aggregation algorithm. Significance tests for differences among groups of samples identified by cluster analysis were carried out using one-way ANOSIM, in which the R-statistic obtained provides an absolute measure of the degree of discrimination between all samples and significance assigned when the $\mathrm{p}$ value obtained was smaller than $5 \%$. The similarity percentage analysis (SIMPER) was used to determine the contribution of the different species to the average similarity between samples. Dominance ranks of species, such as percentage abundance, within each identified assemblage were also obtained.

The total number of species $(\mathrm{N})$, and the median values for Shannon-Wiener diversity $\left(\mathrm{H}^{\prime}\right)$ and Pielou equitability (J') indexes were calculated within each assemblage identified by cluster analysis.

\section{RESULTS}

A total of 51 species, belonging to five major taxa, were collected: 19 bivalves, 15 decapod crustaceans, 7 gastropods, 7 echinoderms and 3 fish (Table 1). The depth range of occurrence of each species is also presented. Among the bivalves, the commonest species was Callista chione, present in over $86 \%$ of the samples taken, followed by Laevicardium crassum, and Acanthocardia aculeata. The commonest decapod crustaceans were the hermit crab Pagurus prideaux (57\%) followed by the brachyurans Thia scutellata and Parthenope angulifrons. Among gastropods, the only 
TABLE 1. - List of species, overall percentage occurrence ( $\mathrm{n}=44$ samples), depth range, and mean density (in number of individuals/200 $\mathrm{m}^{2}$ ) and biomass (in $\mathrm{g} / 200 \mathrm{~m}^{2}$ ) of each species within each assemblage identified: MSS (Medium Sand Shallow), CSS (Coarse Sand Shallow) and CSD (Coarse Sand Deep).

\begin{tabular}{|c|c|c|c|c|c|c|c|c|}
\hline \multirow[b]{2}{*}{ Species } & \multirow{2}{*}{$\begin{array}{l}\text { overall percentage } \\
\text { occurrence }\end{array}$} & \multirow{2}{*}{$\begin{array}{c}\text { depth range } \\
(\mathrm{m})\end{array}$} & \multicolumn{2}{|c|}{ MSS } & \multicolumn{2}{|c|}{ CSS } & \multicolumn{2}{|c|}{ CSD } \\
\hline & & & Density & Biomass & Density & Biomass & Density & Biomass \\
\hline \multicolumn{9}{|l|}{ BIVALVIA } \\
\hline Acanthocardia aculeata (Linnaeus, 1758) & 6.8 & $20-30$ & 0.0 & 0.0 & 0.0 & 0.0 & 0.0 & 0.2 \\
\hline Acanthocardia tuberculata (Linnaeus, 1758) & 45.5 & $5-20$ & 9.8 & 125.1 & 55.6 & 4.2 & 0.3 & 4.0 \\
\hline Atrina sp. & 2.3 & $10-10$ & 0.0 & 0.0 & 0.1 & 0.1 & 0.0 & 0.0 \\
\hline Callista chione (Linnaeus, 1758) & 86.4 & $5-30$ & 7.7 & 62.0 & 27.6 & 135.2 & 101.4 & 899.8 \\
\hline Capsella variegata (Gmelin, 1791) & 13.6 & $5-10$ & 0.2 & 0.2 & 0.1 & 1.6 & 0.0 & 0.0 \\
\hline Chamelea gallina (Linnaeus, 1758) & 11.4 & $6-12$ & 4.0 & 9.2 & 4.1 & 0.0 & 0.0 & 0.1 \\
\hline Dosinia exoleta (Linnaeus, 1758) & 15.9 & $5-13$ & 0.0 & 0.0 & 0.0 & 0.3 & 0.1 & 0.4 \\
\hline Dosinia lupinus (Linnaeus, 1758) & 4.5 & $5-6$ & 0.5 & 0.6 & 0.3 & 0.1 & 0.0 & 0.0 \\
\hline Glycymeris bimaculata (Poli, 1795) & 25 & $5-15$ & 0.0 & 0.0 & 0.0 & 33.8 & 1.6 & 13.8 \\
\hline Laevicardium crassum (Gmelin, 1791) & 56.8 & $5-30$ & 0.0 & 0.0 & 0.0 & 1.7 & 1.8 & 6.4 \\
\hline Laevicardium oblongum (Gmelin, 1791) & 2.3 & $30-30$ & 0.0 & 0.0 & 0.0 & 0.0 & 0.0 & 0.0 \\
\hline Loripes lacteus (Linnaeus, 1758) & 2.3 & $5-5$ & 0.0 & 0.0 & 0.0 & 0.0 & 0.0 & 0.0 \\
\hline Mactra stultorum (Linnaeus, 1758) & 20.5 & $5-12$ & 9.4 & 42.3 & 18.8 & 0.4 & 0.0 & 0.1 \\
\hline Mytilus galloprovincialis (Lamarck, 1819) & 2.3 & $6-6$ & 0.3 & 0.3 & 0.2 & 0.0 & 0.0 & 0.0 \\
\hline Pecten jacobaeus (Linnaeus, 1758) & 6.8 & $5-20$ & 0.0 & 0.0 & 0.0 & 0.0 & 0.1 & 0.3 \\
\hline Solenidae & 2.3 & $5-5$ & 0.0 & 0.0 & 0.0 & 0.1 & 0.0 & 0.0 \\
\hline Tellina sp. & 11.4 & $8-20$ & 0.0 & 0.0 & 0.0 & 0.2 & 0.1 & 0.2 \\
\hline Venus casina Linnaeus, 1758 & 29.5 & $5-30$ & 0.0 & 0.0 & 0.0 & 0.2 & 0.4 & 7.2 \\
\hline Venus verrucosa Linnaeus, 1758 & 4.5 & $20-30$ & 0.0 & 0.0 & 0.0 & 0.0 & 0.1 & 0.8 \\
\hline \multicolumn{9}{|l|}{ GASTROPODA } \\
\hline Aporrhais pespelecani (Linnaeus, 1758) & 2.3 & $30-30$ & 0.0 & 0.0 & 0.0 & 0.0 & 0.0 & 0.0 \\
\hline Bolinus brandaris (Linnaeus, 1758) & 2.3 & $20-20$ & 0.0 & 0.0 & 0.0 & 0.0 & 0.0 & 1.4 \\
\hline Nassarius denticulatus (A. Adams, 1852) & 2.3 & $20-20$ & 0.0 & 0.0 & 0.0 & 0.0 & 0.0 & 0.0 \\
\hline Nassarius reticulatus (Linnaeus, 1758) & 2.3 & $6-6$ & 0.2 & 0.0 & 0.0 & 0.0 & 0.0 & 0.0 \\
\hline Naticarius cruentatus (Gmelin, 1791) & 43.2 & $5-30$ & 0.4 & 3.1 & 1.4 & 0.7 & 0.3 & 2.4 \\
\hline Phalium undulatum (Gmelin, 1791) & 6.8 & $12-30$ & 0.0 & 0.0 & 0.0 & 0.0 & 0.1 & 4.1 \\
\hline Turritella communis Risso, 1826 & 2.3 & $12-12$ & 0.0 & 0.0 & 0.0 & 0.0 & 0.0 & 0.1 \\
\hline \multicolumn{9}{|l|}{ CRUSTACEA DECAPODA } \\
\hline Atelecyclus rotundatus (Olivi, 1792) & 4.5 & $20-30$ & 0.0 & 0.0 & 0.0 & 0.0 & 0.0 & 0.0 \\
\hline Atelecyclus undecimdentatus (Herbst, 1783) & 4.5 & $5-12$ & 0.0 & 0.0 & 0.0 & 0.0 & 0.0 & 0.7 \\
\hline Corystes cassivelaunus (Pennant, 1777) & 4.5 & $6-12$ & 0.2 & 0.2 & 0.1 & 0.0 & 0.0 & 0.0 \\
\hline Diogenes pugilator (P. Roux, 1829) & 9.1 & $5-7$ & 0.4 & 0.1 & 0.1 & 0.1 & 0.0 & 0.0 \\
\hline Ilia nucleus (Linnaeus, 1758) & 11.4 & $5-20$ & 0.0 & 0.0 & 0.0 & 0.0 & 0.1 & 0.3 \\
\hline Inachus communisimus Rizza, 1839 & 2.3 & $20-20$ & 0.0 & 0.0 & 0.0 & 0.0 & 0.0 & 0.0 \\
\hline Liocarcinus bolivari (Zariquiey Álvarez, 1948) & 15.9 & $5-20$ & 0.0 & 0.0 & 0.0 & 0.3 & 0.2 & 0.3 \\
\hline Liocarcinus depurator (Linnaeus, 1758) & 4.5 & $12-20$ & 0.0 & 0.0 & 0.0 & 0.0 & 0.1 & 0.5 \\
\hline Liocarcinus vernalis (Risso, 1827) & 20.5 & $5-12$ & 0.5 & 1.2 & 0.5 & 0.9 & 0.1 & 0.1 \\
\hline Macropodia linaresi Forest \& Zariquiey Álvarez, 196 & 42.3 & $20-20$ & 0.0 & 0.0 & 0.0 & 0.0 & 0.0 & 0.0 \\
\hline Maja crispata Risso, 1827 & 2.3 & $12-12$ & 0.0 & 0.0 & 0.0 & 0.0 & 0.0 & 0.1 \\
\hline Melicertus kerathurus (Forskal, 1775) & 13.6 & $6-24$ & 0.0 & 0.0 & 0.0 & 0.2 & 0.2 & 4.2 \\
\hline Pagurus prideaux Leach, 1815 & 56.8 & $5-24$ & 0.0 & 0.0 & 0.0 & 0.4 & 1.3 & 4.0 \\
\hline Parthenope angulifrons Latreille, 1825 & 50 & $5-24$ & 0.0 & 0.0 & 0.0 & 0.1 & 1.6 & 4.4 \\
\hline Thia scutellata (J.C. Fabricius, 1793) & 54.5 & $5-30$ & 0.0 & 0.0 & 0.0 & 4.6 & 0.4 & 0.6 \\
\hline \multicolumn{9}{|l|}{ ECHINODERMATA } \\
\hline Amphiura sp. & 9.1 & $5-20$ & 0.0 & 0.0 & 0.0 & 0.0 & 0.1 & 0.3 \\
\hline Astropecten aranciacus (Linnaeus, 1758) & 47.7 & $5-30$ & 0.2 & 0.8 & 0.4 & 0.1 & 0.9 & 23.9 \\
\hline Echinaster sepositus (Retzius, 1783) & 2.3 & $30-30$ & 0.0 & 0.0 & 0.0 & 0.0 & 0.0 & 0.0 \\
\hline Echinocardium mediterraneum (Forbes, 1844) & 56.8 & $5-30$ & 5.6 & 8.3 & 3.7 & 0.0 & 7.1 & 26.6 \\
\hline Holothuria tubulosa Gmelin, 1788 & 2.3 & $20-20$ & 0.0 & 0.0 & 0.0 & 0.0 & 0.0 & 0.0 \\
\hline Ophiura texturata Lamarck, 1816 & 43.2 & $5-20$ & 0.5 & 0.3 & 0.1 & 0.5 & 0.8 & 2.3 \\
\hline Spatangus purpureus Müller, 1776 & 20.5 & $12-30$ & 0.0 & 0.0 & 0.0 & 0.0 & 0.8 & 67.3 \\
\hline \multicolumn{9}{|l|}{ PISCES } \\
\hline Arnoglossus thori Kyle, 1913 & 4.5 & $5-20$ & 0.0 & 0.0 & 0.0 & 0.0 & 0.0 & 0.5 \\
\hline Bothus podas (Delaroche, 1809) & 15.9 & $5-30$ & 0.0 & 0.0 & 0.0 & 0.1 & 0.2 & 4.6 \\
\hline Xyrichthys novacula (Linnaeus, 1758) & 2.3 & $15-15$ & 0.0 & 0.0 & 0.0 & 0.0 & 0.0 & 1.4 \\
\hline
\end{tabular}

common species was Naticarius cruentatus (43\%). Several echinoderms appeared commonly in the samples: the sea urchin Echinocardium mediterraneum (57\%), the seastar Astropecten aranciacus (48\%) and the brittlestar Ophiura texturata (43\%).

Cluster analysis (Fig. 2) revealed the occurrence of three main groups of samples. Table 2 summarises the main characteristics of each identified assemblage. The first dichotomy separated, at a similarity level of around $14 \%$, a first group (assemblage MSS; for Medi- um Sand Shallow; see below) of shallow samples (6-7 $m$ depth) from the south of the study area (transects 9 , 11-13) from the rest of both the shallow and deeper samples; thus, showing a geographic effect on the location of assemblages. Within the second dichotomy, two main groups of samples (assemblages CSS (for Coarse Sand Shallow) and CSD (for Coarse Sand Deep)) were identified. Assemblage CSS was formed by a group of shallow samples (5-10 m depth), while assemblage CSD clustered samples deeper than $12 \mathrm{~m}$ (except for 


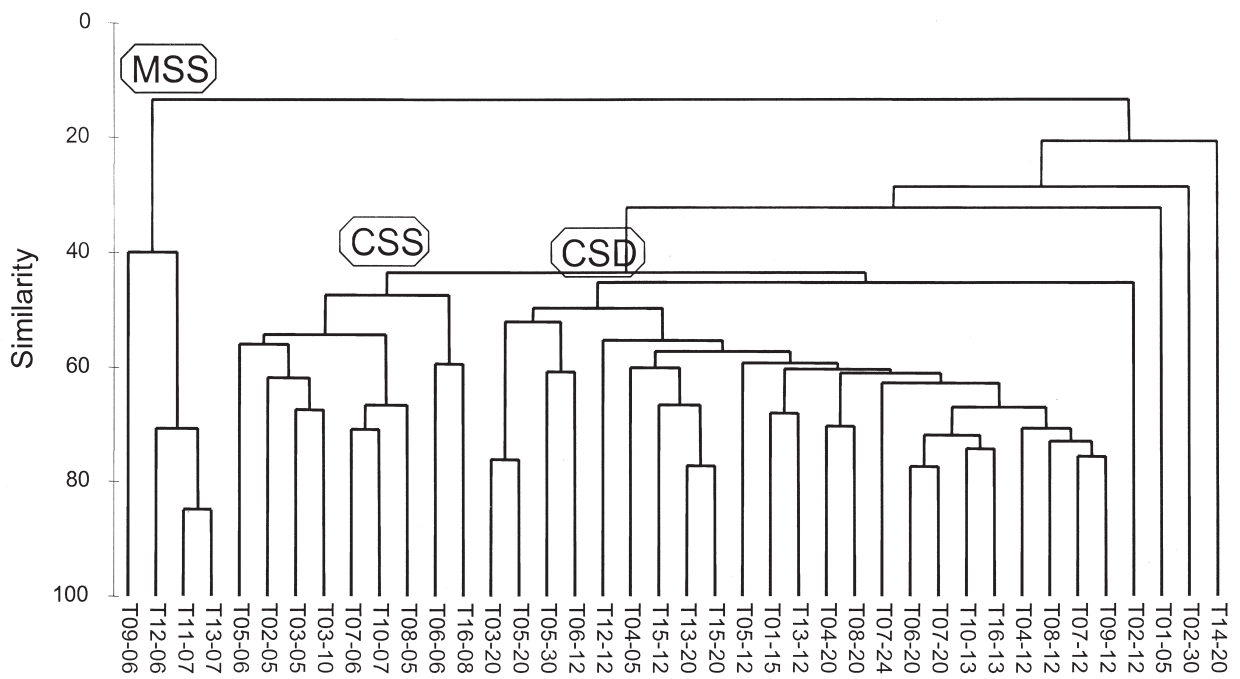

FIG. 2. - Results of the cluster analysis (Bray-Curtis index, UPGMA aggregation algorithm) showing the three main assemblages identified (MSS (Medium Sand Shallow), CSS (Coarse Sand Shallow) and CSD (Coarse Sand Deep)). Each sample is characterised by its transect number (T\#\#) and depth (m).

one $5 \mathrm{~m}$ sample). Four additional samples grouped at a lower level of similarity within this first dichotomy.

The cumulative dominance of species within each identified assemblage (Fig. 3) clearly showed that assemblages CSS and CSD were dominated by one single species, the bivalve Callista chione, which accounted for over $80 \%$ of the numeric abundance within each assemblage. However, the relative dominance within assemblage MSS was rather evenly distributed between three to four species, none of which was $C$. chione.

Multidimensional scaling (Fig. 4) further clarified the relationships between samples. Thus, assemblage MSS appeared clearly differentiated from the rest of the samples. Assemblages CSS and CSD showed their distinctness linked to the $10 \mathrm{~m}$ isobath, while most of the samples not directly attributed to assemblages CSS or CSD were located close to either group CSS or CSD.

In order to determine the occurrence of differences in the faunistic composition of the identified assemblages, an ANOSIM test was performed. This showed significant differences between all combinations of assemblages tested. Thus, the highest $\mathrm{R}$ value $(0.987)$ was found when assemblage MSS was compared with both

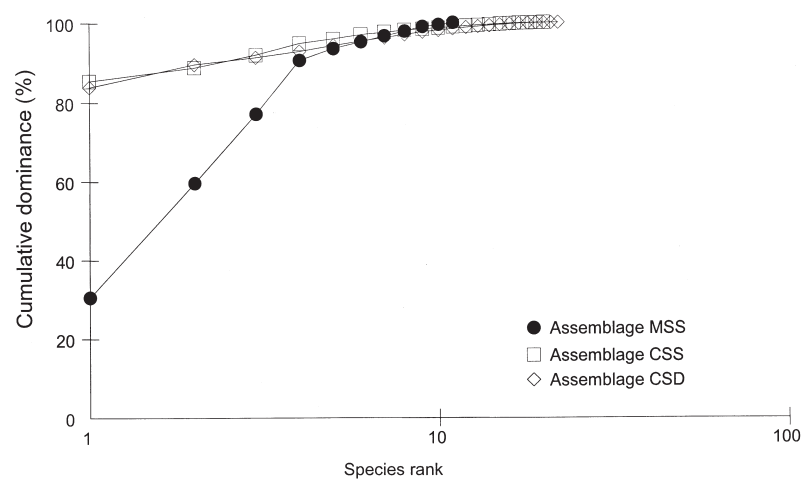

FIG. 3. - Cumulative dominance curves in number of individuals for the three assemblages identified by cluster analysis. MSS (Medium Sand Shallow), CSS (Coarse Sand Shallow) and CSD (Coarse Sand Deep).

assemblages CSS and CSD ( $\mathrm{p}=0.001)$; the comparison of assemblages CSS and CSD yielded an R value of 0.691 , which was also highly significant $(\mathrm{p}=0.001)$.

SIMPER analysis showed that the highest dissimilarity between the three groups of samples was found between MSS and CSD (87.96\%), followed by MSS and

TABLE 2. - Main characteristics (depth, diversity indexes, granulometry and dominant species) of each identified assemblage. Assemblages: MSS (Medium Sand Shallow), CSS (Coarse Sand Shallow) and CSD (Coarse Sand Deep)

\begin{tabular}{|c|c|c|c|}
\hline & MSS & $\begin{array}{l}\text { Assemblage } \\
\text { CSS }\end{array}$ & CSD \\
\hline Mean depth (m) & 6.5 & 6.7 & 16.2 \\
\hline Median depth (m) & 6.5 & 6.0 & 13.0 \\
\hline Depth range $(\mathrm{m})$ & $6-7$ & $5-10$ & $5-30$ \\
\hline Total number of species & 15 & 22 & 36 \\
\hline Median number of species per sample (+ range) & $6(6-11)$ & $8(5-13)$ & $9(4-15)$ \\
\hline Median Shannon-Wiener $\left(\log _{2}\right)$ diversity index (H') (+ range) & $2.05(1.60-2.24)$ & $0.91(0.54-1.16)$ & $1.04(0.31-2.37)$ \\
\hline Median Pielou equitability index (J') (+ range) & $0.72(0.61-0.79)$ & $0.30(0.19-0.50)$ & $0.35(0.11-0.78)$ \\
\hline Dominant granulometry & Medium sands & Coarse sands & Coarse sands \\
\hline Median grain size (mm) (D50) & 0.37 & 0.62 & 0.64 \\
\hline Dominant species (in density) & $\begin{array}{c}\text { Mactra stultorum } \\
\text { Acanthocardia tuberculata }\end{array}$ & Callista chione & Callista chione \\
\hline Number of samples & 4 & 9 & 23 \\
\hline
\end{tabular}




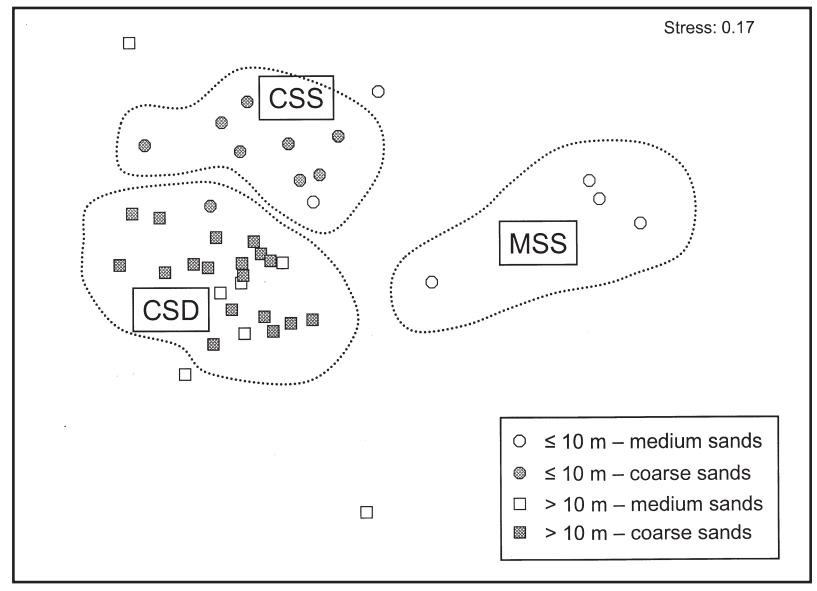

FIG. 4. - Results of the Multi-Dimensional Scaling (MDS) showing the groups detected by cluster analysis (MSS (Medium Sand Shallow), CSS (Coarse Sand Shallow) and CSD (Coarse Sand Deep)). Samples have been classified into four classes: shallower or deeper than $10 \mathrm{~m}$ (circles and squares respectively), and according to their dominant granulometry (coarse (black) or medium (white) sands).

CSS (82.17\%) and CSS and CSD (56.13\%). This analysis was also used to detect the species characterising each assemblage since differences between groups are due to the different contributions of each species to each group. Thus, assemblage MSS was characterised by a similar contribution and mean density of three bivalves: Mactra stultorum (30.5\%), Acanthocardia tuberculata $(30.5 \%)$ and Chamelea gallina (20.0\%); assemblage CSS was clearly dominated by the bivalve Callista chione (59.8\%) and by the crab Thia scutellata (16.2\%); assemblage CSD was also dominated by $C$. chione $(54.2 \%)$ and the sea urchin Echinocardium mediterraneum (14.0\%), with other species making a smaller contribution.

All samples within assemblage MSS were dominated by medium sands (D50 $=0.37 \mathrm{~mm}$ ), whereas assemblages CSS and CSD were dominated by coarse sands $(\mathrm{D} 50=0.62 \mathrm{~mm}$ for assemblage CSS and D50 = $0.64 \mathrm{~mm}$ for assemblage CSD) (Table 2). The profile of sediment size composition (Fig. 5) showed that the sediment structure of assemblage MSS was clearly different from the structure found in assemblages CSS and CSD, which were practically identical to each other. Accordingly, the main dichotomy between assemblages was related to different granulometric characteristics, but not to depth, since both assemblages MSS and CSS showed the same mean depth $(6.5 \mathrm{~m}$ and $6.7 \mathrm{~m}$ respectively). On the contrary, the main difference between assemblages CSS and CSD was related to depth or depth-related factors $(6.7 \mathrm{~m}$ and $16.2 \mathrm{~m}$ respectively), but not to granulometry.

In terms of species richness, the assemblage with the highest number of species was assemblage CSD, the deepest (mean depth: $20.5 \mathrm{~m}$ ), with a total of 36 species (median value of 9 species), followed by assemblage CSS $(6.5 \mathrm{~m})$ with 22 species (median of 8 species), and by assemblage MSS $(6.5 \mathrm{~m})$ with 15 species (median of 6 species) (Table 2). However, the Shannon-Wiener diversity index showed that the most

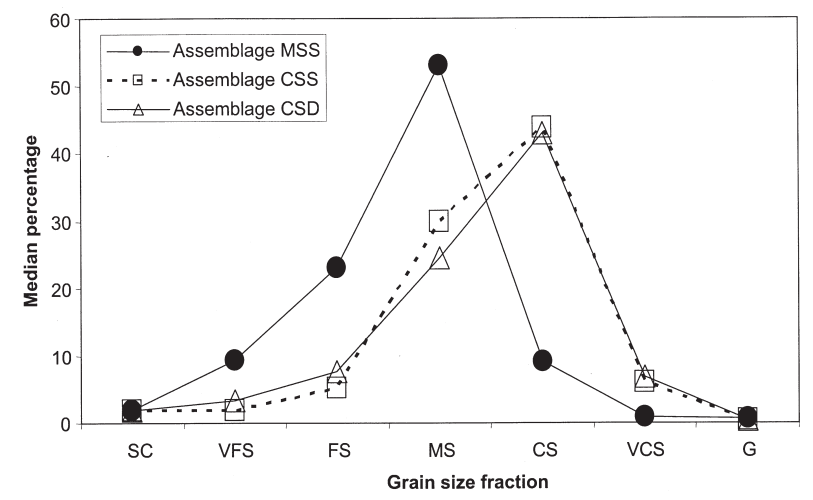

FIG. 5. - Granulometric master profile for the sediment samples belonging to each faunistic assemblage: (MSS (Medium Sand Shallow), CSS (Coarse Sand Shallow) and CSD (Coarse Sand Deep)). G (Gravel): $>2 \mathrm{~mm}$, VCS (very coarse sand): $2.0-1.0 \mathrm{~mm}, \mathrm{CS}$ (coarse sand): $1.0-0.5 \mathrm{~mm}$, MS (medium sand): 0.5-0.25 mm, FS (fine sand) $0.25-0.125 \mathrm{~mm}$, VFS (very fine sand): $0.125-0.063 \mathrm{~mm}$; SC (siltclay): $<0.063 \mathrm{~mm}$.

diverse assemblage (i.e. that in which the information afforded by one individual is the highest) corresponded to the shallow, medium sands assemblage MSS, with a median H' value of 2.05. The values for assemblages CSS and CSD were similar (0.91 and 1.04 respectively) due to the high dominance of Callista chione. In this sense, equitability was much higher in assemblage MSS ( $\left.J^{\prime}=0.72\right)$ than in assemblages CSS and CSD $\left(\mathrm{J}^{\prime}=0.30\right.$ and 0.35 respectively) (see also Table 2$)$.

\section{DISCUSSION}

Despite the socioeconomic importance of sandy beaches in Mediterranean waters (Alarcón Urbistondo, 2002; Ariza et al., 2008), most studies on littoral and shallow benthos composition and dynamics have focused on rocky substrates, very often related to Marine Protected Areas (e.g. Díaz et al., 2005; Linares et al., 2005; Follesa et al., 2007), whereas soft substrates, and particularly sandy beaches, have been somewhat neglected (e.g. Ramón et al., 1995; San Vicente and Sorbe, 1999; Sardá et al., 2000; Zeichen et al., 2002; Pérez-Domingo et al., 2008). Physical factors such as sediment characteristics and wave climate, rather than biological interactions, have been shown to be the main components responsible for the faunistic structure in beach and infralittoral soft bottom ecosystems (Rodil et al., 2006; McLachlan and Dorvlo, 2005; Schlacher et al., 2007). The deep continental shelf, however, has been studied much more, especially from the fisheries point of view (Bertrand et al., 2002; Lleonart, 2005).

The most important fishery associated with Mediterranean sandy beach ecosystems is that targeting bivalve infaunal species, such as Donax trunculus, Chamelea gallina and Callista chione (Ramón et al., 1995; Sardá et al., 2000; Zeichen et al., 2002, Metaxatos, 2004; Morello et al., 2005), which are artisanally captured with small boats using different types of dredges. From the faunistic composition identified in these studies it is clear that very 
different communities inhabit different beaches according to sediment granulometry and the morphodynamic type of the beach (Ramón and Abelló, 2004; Valencia and Massutí, 2004). Thus, the bivalve Donax trunculus, and the decapod crustaceans Portumnus latipes and Diogenes pugilator are the commonest species in very shallow waters of fine sand dissipative beaches, in which $D$. trunculus is the bivalve species targeted by the fishery. A more diverse community is found in deeper waters of fine sand dissipative beaches, and the commonest species are the bivalves Chamelea gallina, Donax semistriatus and Mactra stultorum, the gastropod Nassarius mutabilis and the crabs Liocarcinus vernalis and D. pugilator; $C$. gallina is targeted by the fishery. In coarse sand reflective beaches, as in the communities studied herein, the target species is the bivalve $C$. chione, which is captured in waters deeper than around 4-5 m, together with a few other accompanying bivalves, such as Donax variegatus, D. trunculus and Acanthocardia aculeata (Sardá et al., 1999).The faunistic composition observed in the present study on sublittoral coarse sand bottoms can be ascribed to the characteristic sublittoral coarse to fine sand habitats of the northwestern Mediterranean region defined by the classic work of Pérès and Picard (1964). The quantitative analysis of the densities revealed the occurrence of three main assemblages, characterised by differences in sediment structure and depth, with medium sands clearly segregating the two main faunistic discontinuities, and depth being related to differences among coarse sand samples. Sardá et al. (1999), in a nearby area of coarse to fine-sand sediment, also found that the distribution of macroinfaunal species was related to the gradients of sediment granulometry. In our study, depth was the next main factor to segregate assemblages within coarse sand samples. In other infralittoral megafaunal assemblages, such as in the western Alboran Sea decapod crustacean communities (García-Muñoz et al., 2008), depth, followed by substratum, was the main discriminant factor accounting for assemblage differentiation. In contrast with Sardá et al. (1999), no Spisula subtruncata was found in the present samples. It should be noted that $S$. subtruncata is a short-lived pioneer species (Sardá et al., 2000), highly dependent on annual recruitment, that prefers fine rather than coarse sand sediments to bury in.

A depth breaking point was located at around 10 $\mathrm{m}$, which clearly defined a shallow coarse sand assemblage well separated from a deeper, also coarse sand, assemblage. This depth breaking point is in agreement with the closure depth of the beaches of the study area (Sorribas et al., 1993). The closure depth of a beach separates a high-energy zone along the shallowest part of the beach profile in which sediment movement is high, from a deeper region in which the sediment dynamics due to wave climate action is much lower and can be considered as practically negligible (Guillén and Hoekstra, 1997; Guillén and Palanques, 1997).

Coarse sand bottoms are relatively scarce in the western Mediterranean, appearing only in areas where granitic or volcanic intrusions occur among the mainly calcareous sedimentary rocks (e.g. limestone). Along the Mediterranean shores of the Iberian Peninsula, coarse sand beaches are found only in a relatively small region north of Barcelona (Maresme and Costa Brava) and in the Alboran Sea (Mediterranean coasts of Andalusia). The occurrence of coarse sand beaches coincides with the areas where the bivalve Callista chione is targeted by artisanal fisheries (Salas Casanova et al., 1985; Alarcón Urbistondo, 2002).

That there is a trend for the macroinvertebrate species richness to decrease along the morphodynamic gradient from dissipative to reflective beaches is one of the most supported generalisations in sandy beach ecology (Jaramillo and McLachlan, 1993; Defeo et al., 2009). The scarceness, focus and diversity of methodologies used in megabenthic studies of western Mediterranean beaches, and especially for the associated infralittoral communities, does not allow this generalisation to be tested properly in the area. Faunistic and community studies have been performed in the northwestern Alboran Sea (Salas Casanova et al., 1985; García-Raso, 1987) on bivalve and decapod crustacean communities in coarse sand infralittoral areas, as well as in the Balearic islands (Valencia and Massutí, 2004) and the Valencia region (Ramón and Abelló, 2004) in fine sand beaches. However, it is worth noting that the diversity and equitability were higher in the fine sand shallow community than in the coarse sand shallow community, a characteristic which is probably related to finer sand being less damaging to megabenthic fauna during high energy wave events. This would allow a relatively larger number of species to withstand sand abrasive action in finer rather than in coarser sand areas.

\section{ACKNOWLEDGEMENTS}

We are very grateful to Mauricio Pulido for all his help and kindness during the sampling and to Jorge Guillén (ICM-CSIC) for all his help and comments on the present results. This paper is a result of the research project "Avaluació de l'estat del banc natural de petxina lluenta del Maresme" funded by the Departament d'Agricultura, Ramaderia i Pesca - Generalitat de Catalunya. PA and MR are part of the research group 2009_SGR_1364 of the Generalitat de Catalunya.

\section{REFERENCES}

Alarcón Urbistondo, J.A. - 2002. Inventario de la pesca artesanal en España mediterránea. FAO-COPEMED, Fuengirola.

Ariza, E., J.A. Jiménez and R. Sardá. - 2008. A critical assessment of beach management on the Catalan coast. Ocean Coast. Manag., 51: 141-160.

Benfield, M.C. and R.G. Downer. - 2001. Spatial and temporal variability in the nearshore distributions of postlarval Farfantepenaeus aztecus along Galveston Island, Texas. Est. Coast Shelf Sci., 52(4): 445-456.

Berghahn, R. - 2000. Response to extreme conditions in coastal areas: biological tags in flatfish otoliths. Mar. Ecol. Prog. Ser., 192: $277-285$

Bertrand, J., L. Gil de Sola, C. Papaconstantinou, G. Relini and A. 
Souplet. - 2002. The general specifications of the MEDITS surveys. Sci. Mar., 66(Suppl. 2): 9-17.

Brazeiro, A. - 2001. Relationship between species richness and morphodynamics in sandy beaches: what are the underlying factors? Mar. Ecol. Prog. Ser., 224: 35-44.

Brown, A. C. and A. McLachlan. - 1990. Ecology of sandy shores. Elsevier, Amsterdam.

Clarke, K.R. and R.M. Warwick. - 1994. Changes in marine communities: an approach to statistical analysis and interpretation. Natural Environment Research Council, Plymouth.

Constable, A.J. - 1999. Ecology of benthic macro-invertebrates in soft sediment environments: a review of progress towards quantitative models and predictions. Aust. J. Ecol., 24: 452-476.

Defeo, O. and A. McLachlan. - 2005. Patterns, processes and regulatory mechanisms in sandy beach macrofauna: a multi-scale analysis. Mar. Ecol. Prog. Ser., 295: 1-20.

Defeo O, A. McLachlan, DS. Schoeman, T. Schlacher, J. Dugan, A. Jones, M. Lastra, F. Scapini. - 2009. Threats to sandy beach ecosystems: a review. Estuar. Coast. Shelf. Sci., 81: 1-12.

Díaz, D., M. Zabala, C. Linares, B. Hereu and P. Abelló. - 2005. Increased predation of juvenile European spiny lobster (Palinurus elephas) in a Marine Protected Area. N. Z. J. Mar Freshw. Res., 39: 447-453.

Dolbeth, M., O. Ferreira, H. Teixeira, J.C. Marques, J.A. Dias and M.A. Pardal. - 2007. Beach morphodynamic impact on a macrobenthic community along a subtidal depth gradient. Mar. Ecol. Prog. Ser. 352: 113-124.

Dolbeth, M., H. Teixeira, J.C. Marques and M.A. Pardal. - 2009. Feeding guild composition of a macrobenthic subtidal community along a depth gradient. Sci. Mar., 73(2): 225-237.

Ercilla, G., F. Estrada, D. Casas, R. Durán, M. Nuez, B. Alonso and M. Farrán. - 2010. The El Masnou infralittoral sedimentary environment (Barcelona province, NW Mediterranean Sea): morphology and Holocene seismic stratigraphy. Sci. Mar., 74(1): 179-196

Follesa, M.C., D. Cuccu, R. Cannas, A. Sabatini and A. Cau. - 2007. Emigration and retention of Palinurus elephas (Fabricius, 1787) in a central western Mediterranean marine protected area. Sci. Mar., 71(2): 279-285.

García Muñoz, J.E., M.E. Manjón-Cabeza and J.E. García Raso. 2008. Decapod crustacean assemblages from littoral bottoms of the Alborán Sea (Spain, west Mediterranean Sea): spatial and temporal variability. Sci. Mar., 72(3): 437-449.

García-Raso, J.E. - 1987. Contribución al conocimiento de los crustáceos decápodos de los fondos blandos del sur de España. Graellsia, 43: 153-169.

Guillén, J. and P. Hoekstra. - 1997. Sediment distribution in the nearshore zone: grain size evolution in response to shoreface nourishment (Island of Terschelling, The Netherlands). Est. Coast Shelf Sci., 45: 639-652.

Guillén, J. and A. Palanques. - 1997. A shoreface zonation in the Ebro delta based on grain size distribution. J. Coastal Res., 13(3): 867-878.

Jaramillo, E. and A. McLachlan. - 1993. Community and population responses of the macroinfauna to physical factors over a range of exposed sandy beaches in south-central Chile. Est. Coast Shelf Sci., 37: 615-624.

Lastra, M., R. de La Huz, A. G. Sánchez-Mata, I. F. Rodil, K. Aerts, S. Beloso and J. López. - 2006. Ecology of exposed sandy beaches in northern Spain: Environmental factors controlling macrofauna communities. J. Sea Res., 55: 128-140.

Linares, C., R. Coma, D. Díaz, M. Zabala, B. Hereu and L. Dantart. - 2005. Immediate and delayed effects of a mass mortality event on gorgonian population dynamics and benthic community structure in the NW Mediterranean Sea. Mar. Ecol. Prog. Ser., 305: 127-137.

Lleonart, J. - 2005. Mediterranean and Black Sea, FAO Statistical area 37. FAO Fish. Tech. Pap., 457: 49-64.

McLachlan, A., J. Dugan, O. Defeo, A.D. Ansell, D.M. Hubbard, E. Jaramillo and P.E. Penchaszadeh. - 1996. Beach clam fisheries. Oceanogr. Mar. Biol. Ann. Rev., 34: 163-232.

McLachlan, A. and A. Dorvlo. - 2005. Global patterns in sandy beach macrobenthic communities. J. Coastal Res., 21(4): 674-687.

McLachlan, A., E. Jaramillo, O. Defeo, J. Dugan, A. de Ruyck and P. Coetzee. - 1995. Adaptations of bivalves to different beach types. J. Exp. Mar. Biol. Ecol., 187: 147-160.
Metaxatos, A. - 2004. Population dynamics of the venerid bivalve Callista chione (L.) in a coastal area of the eastern Mediterranean. J. Sea Res., 52: 293-305.

Morello, E.B., C. Froglia, R.J.A. Atkinson and P.G. Moore. -2005. Impacts of hydraulic dredging on a macrobenthic community of the Adriatic Sea, Italy. Can. J. Fish. Aquat. Sci., 62(9): 2076-2087.

Munilla, T. and C. San Vicente. - 2005. Suprabenthic biodiversity of Catalan beaches (NW Mediterranean). Acta Oecol., 27: 81-91.

Pérès, J.M. and J. Picard. - 1964. Nouveau manuel de bionomie benthique de la mer Méditerranée. Rec. Trav. St. Mar. Endoume, 31(47): 1-137.

Pérez-Domingo, S., C. Castellanos and J. Junoy. - 2008.The sandy beach macrofauna of Gulf of Gabès (Tunisia). Mar. Ecol., 29 (Suppl. 1): 51-59.

Ramón, M. and P. Abelló. - 2004. Macrofaunal benthic assemblages of a clam-dredged sandy beach in the Gulf of Valencia (western Mediterranean). Rapp. Comm. int. Mer Médit., 37: 421.

Ramón, M., P. Abelló and C.A. Richardson. - 1995. Population structure and growth of Donax trunculus (Bivalvia: Donacidae) in the western Mediterranean. Mar. Biol., 121: 665-671.

Rufino, M.M., M.B. Gaspar, F. Maynou and C.C. Monteiro. - 2008. Regional and temporal changes in bivalve diversity off the south coast of Portugal. Estuar. Coast. Shelf Sci., 80(4): 517-528.

Rufino, M.M., M.B. Gaspar, A.M. Pereira, F. Maynou and C.C. Monteiro. - 2010. Ecology of megabenthic bivalve communities from sandy beaches on the south coast of Portugal. Sci. Mar., 74(1): 163-178.

Rodil, I.F., M. Lastra and A.G. Sánchez-Mata. - 2006. Community structure and intertidal zonation of the macroinfauna in intermediate sandy beaches in temperate latitudes: North coast of Spain. Est. Coast. Shelf Sci., 67: 267-279.

Salas Casanova, C., J.E. García Raso and A. López-Ibor. - 1985. Estudio del macrobentos infralitoral (Mollusca, Crustacea Decapoda y Echinodermata) de la Bahía de Málaga (España). Actas do IV Simposio Iberico de Estudos do Benthos Marinho. Lisboa; 21-25 Maio 1984, 1: 123-146.

San Vicente, C. and J.C. Sorbe. - 1999. Spatio-temporal structure of the suprabenthic community from Creixell beach (western Mediterranean). Acta Oecol., 20(4): 377-389.

Sardá, R., S. Pinedo and D. Martin. - 1999. Seasonal dynamics of macroinfaunal key species inhabiting shallow soft-bottoms in the Bay of Blanes (NW Mediterranean). Acta Oecol., 20(4): 315-326.

Sardá, R., S. Pinedo, A. Gremare and S. Taboada. - 2000. Changes in the dynamics of shallow sandy-bottom assemblages due to sand extraction in the Catalan Western Mediterranean Sea. ICES J. Mar. Sci., 57: 1446-1453.

Schlacher, T.A., J. Dugan, D.S. Schoeman, M. Lastra, A. Jones, F. Scapini, A. McLachlan and O. Defeo. - 2007. Sandy beaches at the brink. Div. Distrib., 13: 556-560.

Schoeman, D.S., A. McLachlan and J.E. Dugan. - 2000. Lessons from a disturbance experiment in the intertidal zone of an exposed sandy beach. Est. Coast Shelf Sci., 50: 869-884.

Selleslagh, J. and R. Amara. - 2008. Inter-season and interannual variations in fish and macrocrustacean community structure on a eastern English Channel sandy beach: Influence of environmental factors. Est. Coast Shelf Sci., 77: 721-730.

Sorribas, J., J. Serra and A.M. Calafat. - 1993. Límites dinámicos y modos de transporte en el litoral del Maresme (Barcelona). Geogaceta, 14: 24-26.

Underwood, A.J. and M.G. Chapman. - 1996. Scales of spatial patterns of distribution of intertidal invertebrates. Oecologia, 107: 202-224.

Valencia, J.M. and E. Massutí. - 2004. Comunitat dels fons d'arenes fines de la platja de Palma (Mallorca, Illes Balears). Boll. Soc. Hist. Nat. Balears, 47: 31-37.

Wright, L.D. and A.D. Short. - 1984. Morphodynamic variability of surfzones and beaches: A synthesis. Mar. Geol., 56: 93-118.

Zeichen, M., S. Agnesi, A. Mariani, A. Maccaroni and G.D. Ardizzone. -2002 . Biology and population dynamics of Donax trunculus L. (Bivalvia: Donacidae) in the South Adriatic coast (Italy). Est. Coast Shelf Sci., 54(6): 971-982.

Scient. ed.: F. Maynou.

Received January 13, 2010. Accepted July 19, 2010.

Published online January 11, 2011. 